\title{
Ethanol Injection Under Ultrasound Guidance to Palliate Unresectable Parathyroid Carcinoma
}

\begin{abstract}
Background: Severe hypercalcemia is the leading cause of death in patients with parathyroid carcinoma. Non-curative resection and pharmacological measures may be useful for palliation in cases with recurrent and metastatic disease. Palliative treatment with intra-neoplastic ethanol injection has not been reported yet. Methods: Ultrasound-guided percutaneous alcohol injection in one patient with unresectable parathyroid carcinoma is reported. Results: One male patient with extensive recurrent parathyroid carcinoma suffering from severe hypercalcemia, refractory to all available medical measures has undergone two percutaneous ethanol injections. No major complications ensued and parathormone levels decreased from $2,990 \mathrm{pg} / \mathrm{mL}$ to $2,230 \mathrm{pg} / \mathrm{ml}$ after the first injection, and to $1,104 \mathrm{pg} / \mathrm{mL}$ after the second one. Calcium levels decreased from $19.8 \mathrm{mg} / \mathrm{dL}$ to $16.1 \mathrm{mg} / \mathrm{dL}$ and to $14.5 \mathrm{mg} / \mathrm{dL}$, respectively. The patient died of metabolic hypercalcemia complications about two months later, probably due to mediastinal disease progression. Conclusion: Ultrasound-guided percutaneous ethanol injection may be employed to palliate parathyroid carcinoma in selected cases, with a transitory decrease in PTH and calcium levels. Arq Bras Endocrinol Metab 2008; 52/4:707-711)
\end{abstract}

Key-words: Hyperparathyroidism, primary; Parathyroid neoplasms; Parathyroid hormone; Parathyroid glands; Hypercalcemia; Ultrasonography, Interventional.

\section{RESUMO}

Injeção Percutânea de Etanol Guiada por Ultra-Sonografia para Paliação de Carcinoma de Paratireóide Não-Extirpável.

Introdução: A hipercalcemia severa é a principal causa de óbito nos pacientes com carcinoma de paratireóide. Em casos com recidiva ou doença metastática inoperáveis, a ressecção não curativa e as medidas farmacológicas podem ser úteis para a paliação. $O$ presente estudo relata a experiência com a injeção de etanol na neoplasia para tratamento paliativo em um caso. Método: Relato da injeção percutânea de etanol em paciente com carcinoma de paratireóide recidivado, não passível de ressecção. Resultado: Paciente masculino com hipercalcemia refratária a tratamento clínico decorrente de recidiva local não extirpável de carcinoma de paratireóide. Submetido a duas sessões de injeção percutânea de etanol. Não houve complicações maiores. Após a primeira injeção, o nível de paratormônio reduziu-se de $2.990 \mathrm{pg} / \mathrm{mL}$ para $2.230 \mathrm{pg} / \mathrm{ml}$. Após a segunda injeção, o nível caiu para $1.104 \mathrm{pg} / \mathrm{mL}$. A calcemia declinou de $19,8 \mathrm{mg} / \mathrm{dL}$ para $16,1 \mathrm{mg} / \mathrm{dL}$ e $14,5 \mathrm{mg} / \mathrm{dL}$, respectivamente. O paciente faleceu de complicação metabólica, cerca de dois meses depois, possivelmente pela progressão da doença no mediastino. Conclusão: A injeção percutânea de etanol pode ser utilizada para paliação do carcinoma de paratireóide em casos selecionados, com queda transitória do nível de hormônio da paratireóide e da calcemia. Arq Bras Endocrinol Metab 2008; 52/4:707-711)

Descritores: Hiperparatireoidismo primário; Neoplasias das paratireóides; Hormônio paratireóideo; Glândulas paratireóides; Hipercalcemia; Ultra-sonografia de intervenção.

\section{apresentação}

de caso

Fábio luiz de Menezes Montenegro
Maria CRISTINA Chammas

Adriana Gonçalves Juliano

Claudio Roberto Cernea

anó CAstro Cordeiro

Disciplina de Cirurgia de

Cabeça e Pescoço do

Departamento de Cirurgia

(FLMM, CRC, ACC); Setor de

Ultra-Sonografia do

Departamento de Radiologia

(MCC); Departamento de

Radiologia (AGJ) do Hospital das

Clínicas da Faculdade de

Medicina da Universidade de

São Paulo (HC-FMUSP), SP, Brasi.

Recebido em 28/08/2007

Aceito em 3/04/2008 


\section{INTRODUCTION}

P ARATHYROID CARCINOMA IS considered a rare disease, comprising less than $1 \%$ of patients with primary hyperparathyroidism in some series (1). A relatively higher incidence was reported in Italy and Japan (2). In Brazil (3), although the incidence reached $6.1 \%$ at the University of Sao Paulo Medical School from 1995 to 2000 , the incidence dropped to $1.9 \%$ from 1996 to 2005 , probably due to the increased diagnosis and surgical treatment of less symptomatic parathyroid adenoma patients.

In some series, the clinical presentation of parathyroid carcinoma was not different from that of parathyroid adenoma (4). Conversely, some authors reported that patients with parathyroid malignancy usually presented marked hypercalcemia and a palpable mass (1-3). This information may help the surgeon during cervical exploration, in order to perform a complete operation, and to avoid recurrence (5). Recurrence is rarely curable, and death is frequently related to severe hypercalcemia (6). Although rarely curable, recurrence may be treated by radical surgery to alleviate hypercalcemia (7). Postoperative radiotherapy may be effective as an adjuvant treatment for microscopic residual disease or for close margins (8). but apparently it is not effective for gross residual disease. Similarly, chemotherapy is not successful (9).

When all conventional therapeutic measures have failed to control the tumor, clinical management of hypercalcemia is recommended to postpone death. Parenteral bisphosphonates and cinacalcet are the most effective available drugs to lessen the catastrophic effect of excessive parathyroid hormone (PTH) (10). A very impressive result of anti-PTH immunization was reported, achieving not only metabolic control but also metastases regression (11). To our knowledge, palliative treatment of parathyroid carcinoma with ethanol injection has not previously reported in literature, and the experience observed in one case is here discussed.

\section{PATIENT REPORT}

In December 1998, a 50 year-old man went to our Institution with a two-month history of spontaneous rib fracture and asthenia. He has complained of renal stones for the past ten years and reported a thyroid operation 20 years ago. He had a palpable cervical mass, associated with total calcium level of $13.2 \mathrm{mg} / \mathrm{dl}$ (normal range $8.5-10.5 \mathrm{mg} / \mathrm{dl}$ ) and a PTH of $625 \mathrm{pg} / \mathrm{ml}$ (normal range 13 to $54 \mathrm{pg} / \mathrm{ml}$ ). A computerized tomography showed a mass behind the left thyroid lobe, extending to the retropharyngeal space. With a clinical suspicion of parathyroid carcinoma, the patient was submitted to a presumed complete resection including the left thyroid lobe and left tracheoesophageal groove lymph node resection. The thyroid lobe was grossly invaded and seven lymph nodes were negative. The parathyroid tumor measured 8.0 x 5.0 x $3.0 \mathrm{~cm}$. Unfortunately, the final pathology report disclosed positive microscopic retropharyngeal surgical margin. PTH level decreased to $1.6 \mathrm{pg} / \mathrm{ml}$ (normal range 12 to $72 \mathrm{pg} / \mathrm{ml}$ ), and calcium supplements were necessary, as hungry bones syndrome ensued. Based on previous institutional experience with radiotherapy for parathyroid carcinoma, only a watchful policy was advised. The patient had no evidence of disease on follow up evaluation in May 1999, with normal both total and ionized serum calcium.

He had been away until his next follow up in September 2000 , when total calcium was of $13,2 \mathrm{mg} / \mathrm{dl}$ and PTH was elevated at $353 \mathrm{pg} / \mathrm{ml}$. Imaging work-up revealed an extensive recurrence in retropharyngeal space from the right side to the left, extending to mediastinum and involving esophagus and the membranous portion of the trachea. He underwent palliative sessions of pamidronate, with initial good response. At the end of 2001, he was refractory to medical therapy, and his clinical condition deteriorated, having anemia and decline of renal function. At this time, calcium blood level was $18.0 \mathrm{mg} /$ dl. At laryngoscopy, the right vocal cord palsy was observed and a palliative resection of the right side mass was performed. A $6.5 \mathrm{x} 4.0 \mathrm{x} 4.0 \mathrm{~cm}$ mass was excised, causing a small pharyngeal defect, which was closed primarily, with no further complication. Graphic 1 depicts the marked decrease of PTH, which was accompanied by a calcium decline to $12.6 \mathrm{mg} / \mathrm{dl}$. Postoperatively, conformational radiotherapy was used, totalling 7,020 cGy, associated with two cycles of $400 \mathrm{mg} / \mathrm{m}^{2}$ dacarbazide. He received a monthly dose of $90 \mathrm{mg}$ of pamidronate. His condition was stable until October 2003, when calcium reached $19.8 \mathrm{mg} / \mathrm{dl}$ and he was unresponsive to pamidronate and saline hydration with forced diuresis. It was considered the possibility to develop a vaccine against the tumor or PTH, but the technology was unavailable at our Institution at that time. The surgeons authoring this paper considered the possibility of another 


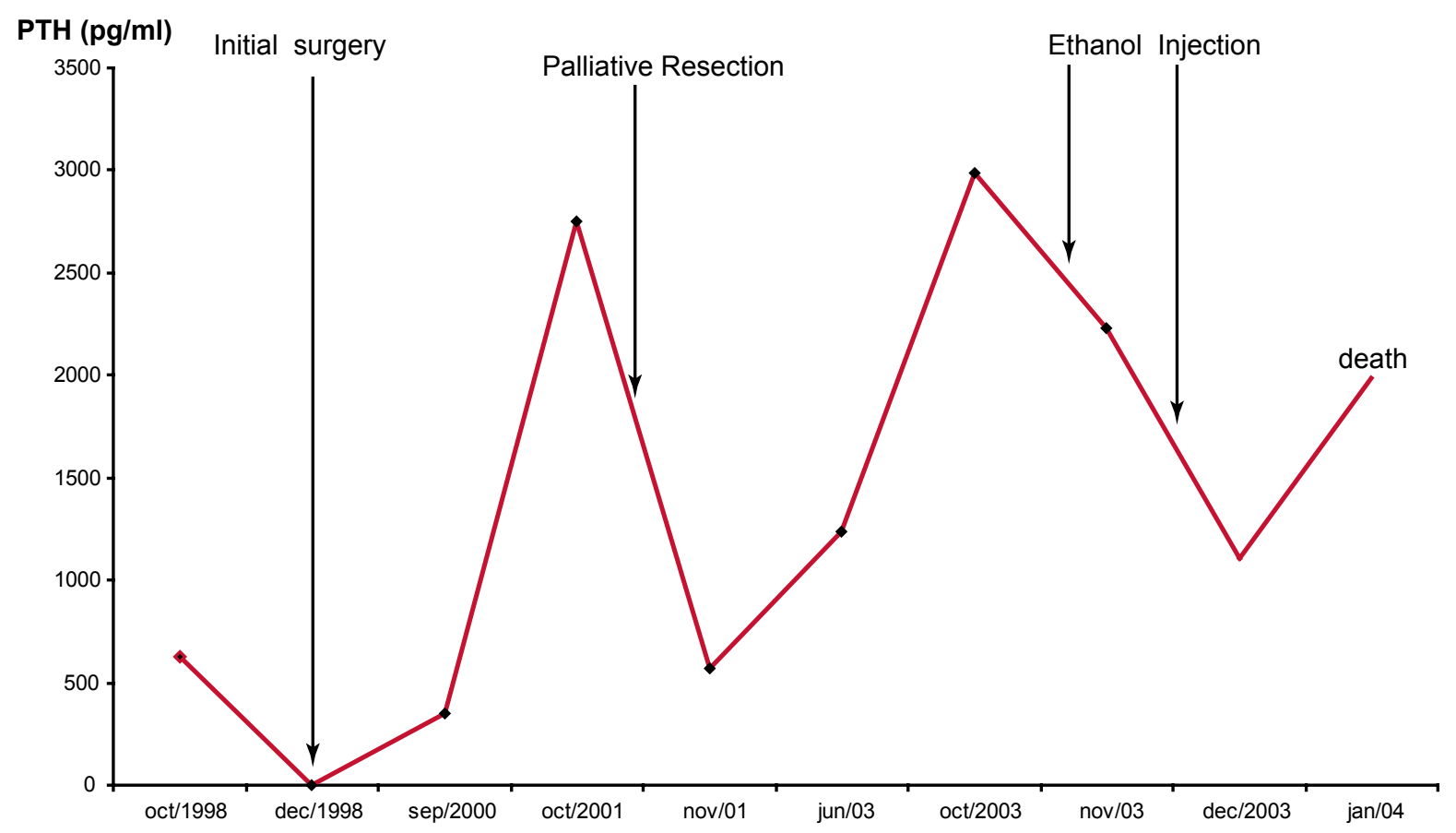

Graphic 1. PTH levels during patient's disease evolution.

palliative resection, but the procedure was not accepted by the majority of other staff surgeons at the tumor board meeting.

After signing an informed consent, he underwent two separate sessions of $95 \%$ ethanol injection under ultrasound guidance with a 23-day-interval. The injections were performed by an experienced radiologist (MCC). In both sessions a surgeon was present. In the first evaluation with Doppler ultrasound, well vascularized masses of $9.3 \mathrm{ml}$ on the right side and of $16.6 \mathrm{ml}$ on the left side were observed. Volumes of $2.5 \mathrm{ml}$ and $1.2 \mathrm{ml}$ were injected on the right side and left side, respectively. The patient complained of tolerable pain during the procedure. No local or systemic complications related to ethanol were observed. PTH levels were of $2,230 \mathrm{pg} / \mathrm{ml}$ after the first injection and calcium levels decreased from $19.8 \mathrm{mg} / \mathrm{dL}$ to 16.1 $\mathrm{mg} / \mathrm{dL}$. On the second procedure, volumes of $8.9 \mathrm{ml}$ on the right side and $15.0 \mathrm{ml}$ on the left were seen. Under sedation with midazolam, $4.5 \mathrm{ml}$ of ethanol were injected in the right tumoral mass, but only 0.3 $\mathrm{ml}$ on the left side, as the patient refused any further injection. No complication ensued. Although a significant volume of the lesion was on the left side, it was preferred to use larger volumes on the right side whe- re recurrent laryngeal nerve was previously sacrificed. Although there was a marked decrease in PTH levels, as show in graphic 1 , calcium levels remained around $14.5 \mathrm{mg} / \mathrm{dl}$. Two months later, PTH and calcium started to rise again, probably due to the progression of the tumor. His clinical condition became critical and he died soon after.

This patient was included in a previous communication (3), but details of his treatment were not previously described.

\section{DISCUSSION}

In spite of its rarity, parathyroid carcinoma is still a therapeutic challenge (12). The etiology is unknown and surgery is the single most effective therapy when complete resection is achieved at the time of initial operation. Thus, preoperative suspicion and intraoperative recognition are of paramount importance (13). In the present case, even though a preoperative and intraoperative suspicion led to a presumed complete operation, there was microscopic residual disease. Retrospectively, adjuvant radiotherapy should be advised at that moment, to prevent tumor regrowth (13). 
In 2005, Kameyama and Takami suggested that parathyroid carcinoma should be divided in low-grade (i.e., minimally invasive type) and high-grade (i.e., widely invasive type) (14). The experience in the present case concurs with their opinion. In 1999, Shaha and Shah proposed a staging system for parathyroid carcinoma (12). According to their system, the present case would be staged as T3 ("primary tumor of any size with invasion of the surrounding soft tissues, such as the thyroid gland and strap muscles"). If this staging system is to be adopted, T4 should include any high grade-tumor and not only those with "massive central compartment disease invading the trachea and esophagus or recurrent parathyroid carcinoma" (12).

Alcohol injection is clearly not the therapy of choice for parathyroid disease, but there are some relative indications in a very small number of selected patients (15). This technique may be helpful to palliate metabolic complications of parathyroid carcinoma. A marked decrease of PTH was observed in the present case. A possible argument against its use in such clinical scenario could be the observation that, in fact, it did not postpone the patient's death very long. Nevertheless, it was employed only when the patient's metabolic derangement (renal function and hydration) was far advanced, i.e., leading to a very critical and desperate clinical situation. Perhaps if ethanol injection had been employed earlier, the clinical course could have been slightly more favorable.

Another point would be that other clinical measures employed may confound the interpretation of the ethanol injection therapeutic effect. Saline hydration with large volumes, diuretics and bisphophonates decrease calcium levels but not PTH. PTH reduction occurred only after ethanol injection, while all clinical measures had started earlier. Indeed, PTH decrease after ethanol injection resembles that observed after palliative resection, as observed in the graphic. It is reasonable to suppose that PTH decrease may have occurred by the destruction of neoplastic cells.

One considerable problem for ethanol ablation is the volume to be injected. Larger volumes are less tolerated and add a significant risk of complications. Additionally, there is always the possibility to implant parathyroid carcinoma in the needle tract $(16,17)$. In fact, this was a potential complication in the present case, but the procedure was considered the last available palliative method at that time.
Fortunately new palliation alternatives have been added since 2003. Cinacalcet $\mathrm{HCl}$ proved to be an effective drug in parathyroid carcinoma hypercalcemia, but the remarkable result obtained after anti-PTH immunotherapy in one case with metastatic disease suggests that parathyroid immunology should deserve a deeper investigation. The result reported by Betea e col. in 2004 confirmed a previous report of the same group and it seems to open a promising window in the management of unresectable recurrent parathyroid carcinoma (11).

Evidently, a better understanding of the disease is mandatory, in order to develop more precise targeted therapies. A better prognosis is expected with the improvement in the management of hypercalcemia (18). Meanwhile, the present case adds a palliative therapeutic option for this intriguing disease. Another observation is that a significant decrease in PTH levels right after the surgery cannot be an indicative of an effective resection. Intraoperative analysis of intact PTH may not indicate a complete resection and its role in parathyroid cancer surgery is questionable $(1,2)$.

In conclusion, ultrasound guided percutaneous ethanol injection may be employed to palliate parathyroid carcinoma, with a transitory decrease in PTH and calcium levels.

\section{REFERENCES}

1. Mittendorf EA, McHenry CR. Parathyroid carcinoma. J Surg Oncol. 2005;89:136-42.

2. Lumachi F, Basso SMM, Basso U. Parathyroid cancer: etiology, clinical presentation and treatment. Anticancer Res. 2006;26:4803-8.

3. Montenegro FLM, Tavares MR, Durazzo MD, Cernea CR, Cordeiro AC, Ferraz AR. Clinical suspicion and parathyroid carcinoma management. S Paulo Med J. 2006;124(1):42-4.

4. Agarwal G, Prasad KK, Kar DK, Krishnani N, Pandey R, Mishra SK. Indian primary hyperpathyroidism patients with parathyroid carcinoma do not differ in clinicoinvestigative characteristics from those with benign parathyroid pathology. World J Surg. 2006;30:732-42.

5. Kirby-Bott J, Lewis $\mathrm{P}$, Harmer CL, Smellie WJB. One stage treatment of parathyroid cancer. EJSO. 2005;31:78-83.

6. Cordeiro A, Montenegro FL, Kulcsar MA, DellaNegra LA, Tavares MR, Michaluart Jr P, et al. Parathyroid carcinoma. Am J Surg. 1998; 175:52-5.

7. Dotzenrath C, Goretzki PE, Sarbia M, Cupisti K, Feldkamp J, Röher HD. Parathyroid carcinoma: problems in diagnosis and the need for radical surgery even in recurrent disease. EJSO. 2001;27:383-89.

8. Chow E, Tsang RW, Brierley JD, Filice S. Parathyroid carcinoma-the Princess Margaret Hospital experience. Int J Radiation Oncology Biol Phys. 1998;41:569-72. 
9. Koea JB Shaw JHF. Parathyroid carcinoma: biology and management Surg Oncol. 1999;8:155-65.

10. Rodgers S, Perrier N. Parathyroid carcinoma. Curr Opin Oncol. 2006;18(1):16-22.

11. Betea D, Bradwell AR, Harvey TC, Mead GP, Schimdt-Gayk $H$, Ghaye B, et al. Hormonal and biochemical normalization and tumor shrinkage induced by anti-parathyroid hormone immunotherapy in a patient with metastatic parathyroid carcinoma. J Clin Endocrinol Metab. 2004;89:3413-20.

12. Shaha A, Shah J. Parathyroid carcinoma. A diagnostic and therapeutic challenge. Cancer. 1999;86(3):378-80.

13. Shane E. Parathyroid carcinoma. J Clin Endocrinol Metab. 2001;86(2):485-93.

14. Kameyama K, Takami H. Proposal for the histological classification of parathyroid carcinoma. Endocr Pathol. 2005;16(1):49-52.

15. Harman CR, Grant CS, Hay ID, Hurley DL, van Heerden JA, Thompson GB, et al. Indications, technique, and efficacy of alcohol injection of enlarged parathyroid glands in patients with primary hyperparathyroidism. Surgery. 1998;124:1011-20.
16. Agarwal G, Dhingra S, Mishra SK, Krishnani N. Implantation of parathyroid carcinoma along fine needle aspiration track. Langenbecks Arch Surg. 2006;391:623-6.

17. Spinelli C, Bonadio AG, Berti P, Materazzi G, Miccoli P. Cutaneous spreading of parathyroid carcinoma after fine needle aspiration cytology. J Endocrinol Invest. 2000;23:255-7.

18. Vieira JGH, Ohe MN, Hauache OM, Oliveira UM, Delana JM, Gonçalves A, et al. Carcinoma de paratiróide. Arq Bras Endocrinol Metab. 2005;49(5):811-5.

\section{Endereço para correspondência:}

Fabio Luiz de Menezes Montenegro

Rua Apeninos, 1118 , apto. 62

04104-021 São Paulo, SP

E-mail: fabiomonte@uol.com.br 